\title{
Biological Effects of Propolis on Cancer
}

\author{
Hamide Doğan ${ }^{1, a, *}$, Sibel Silici ${ }^{2, b}$, Ahmet Ata Özcimen ${ }^{1, c}$ \\ ${ }^{1}$ Department of Biology, Faculty of Arts and Sciences, Mersin University, 33110 Mersin, Turkey \\ ${ }^{2}$ Agricultural Biotechnology Department, Seyrani Faculty of Agriculture, Erciyes University, 38030 Kayseri, Turkey \\ ${ }^{*}$ Corresponding author

\begin{tabular}{l|l}
\hline A R T I C L E I N F O & A B S T R A C T \\
\hline Review Article & $\begin{array}{l}\text { Propolis is a special resin and wax material collected from the leaves and shells of trees, buds and } \\
\text { shoots of plants by honey bees (Apis mellifera L.). In recent years, many researchers have studied } \\
\text { the chemical composition, biological activity and pharmacological properties of propolis. The } \\
\text { colour, odour and pharmacological properties of the propolis composition also vary as the } \\
\text { composition changes depending on the plant, region, season and bee colony. Flavonoids, aromatic } \\
\text { acids, phenolic acids and esters are the main compounds responsible for the biological activity of } \\
\text { propolis. A number of studies have been conducted on the use of propolis or its active ingredients in } \\
\text { the treatment of cancer. It has been observed that the use of propolis did not cause side effects } \\
\text { according to in-vitro and in-vivo studies. Propolis should be extracted with different compounds for } \\
\text { use in biological assays. The most commonly used compounds for extraction are ethanol, methanol, } \\
\text { Received : 06/09/2019 } \\
\text { Accepted : 08/01/2020 } \\
\text { in cell culture and animal tests. The search for new drugs derived from natural products, which may } \\
\text { function as chemotherapeutic agents and have low side effects, has increased in recent years. } \\
\text { Combination with antioxidant therapy may improve the side effects of chemotherapy on leukocytes, } \\
\text { liver and kidney, thus increasing the effect of chemotherapy with dose increase. }\end{array}$ \\
$\begin{array}{l}\text { Keywords: } \\
\text { Anticancer }\end{array}$ & $\begin{array}{l}\text { Entitumor } \\
\text { Flavonoid } \\
\text { Propolis }\end{array}$
\end{tabular}

Türk Tarım - Gıda Bilim ve Teknoloji Dergisi, 8(3): 573-579, 2020

\section{Kanserde Propolisin Biyolojik Etkileri}

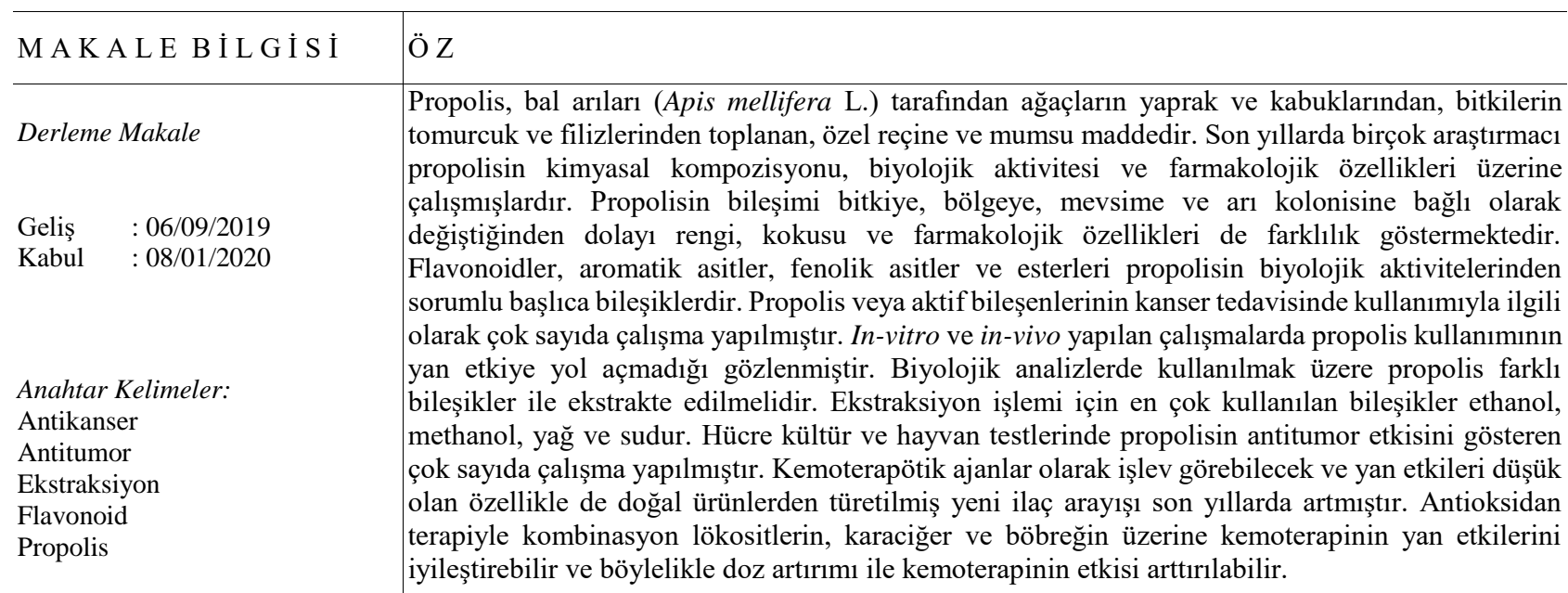




\section{Introduction}

\section{What is The Propolis?}

In general terms propolis, which its content may be varied depending on vegetation and is obtained with modification as biochemical with saliva enzymes of honeybee of resin and waxy substances collected from leaves, shells, buds and shoots of plants by honeybees; it is used for many purposes (such as covering the inner surface of the hive, closing the crevices and cracks, hardening and repairing the edges of the combs, connecting the frames at the end of the summer, shrinking the hive entrance hole, and polishing the honeycomb eyes before laying the queen) by honeybees (Kumazawa et al., 2004; Kutluca et al., 2006; Silici and Güçlü, 2010; Doğan et al., 2014). Propolis, which has been widely used in medicine to treat and reduce the effects of various diseases since ancient times and praised by Hippocrates, Herodotus, Aristotle and other ancient scholar (Bogdanov, 2016).

The color of propolis, an adhesive and resinous substance, can vary from yellow-green to dark brown depending on the source from which it is obtained and the storage time (Silici, 2003; Silici and Güçlü, 2010). The color differences of propolis may vary depending on the concentration of phenolic compounds it contains. It has been reported that the propolis contains flovanoids, essential oils, cinnamyl alcohol, cinnamic acid and trace amounts of vanillin that give wax color (Şahinler, 2000). Propolis, which can darken during storage and lose its elasticity by the effect of sun rays, becomes brittle which can harden and break easily when the temperature of the environment is below $15^{\circ} \mathrm{C}$. Propolis, which has a melting temperature of $80^{\circ} \mathrm{C}$ to $105^{\circ} \mathrm{C}$, generally soluble in alcohol (ethanol, methanol); dissolves in water and hydrocarbons in a small amount, but completely soluble in ether or chloroform (Schmidt, 1997). In most of the studies, ethanolic extract of propolis has been used for a long time. Although extraction of propolis with alcohol and its derivatives is seen as a simple and effective method, it has a sharp resinous taste and limitations in its use in the cosmetic and pharmaceutical industries. However, the medical use of propolis alcohol extraction is not considered appropriate due to some disadvantages such as lead to harmful reactions and alcohol intolerance in some people (Konishi et al., 2004). In water extraction of propolis, it is reported that phenolic compounds are 10 times lower than ethanolic extraction due to the low water solubility of the active components of propolis (Mello et al., 2010; Moura et al., 2009). For this reason, researchers have started to obtain high activity propolis extract by using non-chemical natural solvents other than ethyl alcohol, propylene glycol and glycerol. Therefore, the dissolution of propolis with vegetable oils and the biological activities of oil-soluble phenolic compounds are of interest.

The composition of propolis, which is highly complex in chemical composition, varies in color, odor and pharmacological properties as it varies depending on the plant, region, season and colony. Propolis, which may have more than three hundred components; It contains $50 \%$ resin and balsam, 30\% wax, $10 \%$ essential and aromatic oils, 5\% pollen and $5 \%$ other organic matter (Castaldo and Capasso, 2002). The components of propolis soluble in solvents such as alcohol contain medically important components. Basic chemicals determined in propolis; polyphenols (flavonoid aglycones, phenolic acids) and their esters, phenolic aldehydes, alcohols and ketones, sesquiterpene quinones, coumarins, stereoids, amino acids and inorganic compounds. In the content of propolis, phenolic acids such as pinosembrine, acacetin, chrisin, routine, catesin, naringenin, galangin, luteolin, camferol, apigenin, mirsetin, quarcetin, phenolic acids such as caffeic acid and cinnamic acid, $\mathrm{Mg}, \mathrm{Ca}, \mathrm{I}, \mathrm{K}, \mathrm{Na}, \mathrm{Cu}, \mathrm{Zn}, \mathrm{Mn}$ and $\mathrm{Fe}$ elements, vitamins such as B1, B2, B6, A, C, E, niacin, pantothenic acid (Özan, 2006; Cantarelli et al., 2011), enzymes such as succinic dehydrogenase, glucose-6phosphatase, adenosine triphosphatase, acid phosphatase and a plurality of fatty acids (Table 1) (Bankova et al., 2000; Kutluca et al., 2006; Silici, 2003; Marcucci et al., 2001; Moreno et al., 2000). In addition, proteins, amides, amines and amino acids $(0.7 \%$; aspartic acid, glutamic acid, tryptophan, phenylalanine, leucine, cysteine, methionine, valine, serine, histidine, arginine, proline, tyrosine, threonine, alanine and lysine) are present in the propolis as the nitrogen source (Güney and Y1lmaz, 2013). Besides these contents, it also contains prenylated pcoumaric acids, acetophenone derivatives, lignans, diterpenic acids, triterpenes, volatile components, monoterpenes, sesquiterpenes, aromatic components (xylose, galactose, mannose, glucuronic acid, lactose, maltose, melibiozyl, erythritol, etc.) (Bankova et al., 2000).

In recent years, many researchers have focused on the chemical composition, biological activity, pharmacological and therapeutic properties of propolis.

\section{What are the Biological Properties of Propolis?}

Flavonoids, aromatic acids, phenolic acids and esters are the main compounds responsible for the biological activities of propolis. Propolis, which was discovered by Greeks for the first time in ancient times and used as a natural antibiotic, is used in medicine, apiterapy and biocosmetic fields due to its antibacterial, antiviral, antifungal, antiparasitic, antioxidant, immunostimulatory and liver protective effects (Silici and Güçlü, 2010; Doğan et al., 2014).

As a source of the antimicrobial properties of propolis; flavonoids, pinosembrin, galangin and pinobanksin might be included. Pinosembrin has also antifungal properties (Marcucci, 1995). As a result of research, the content of the antibacterial properties of propolis from prenylated pcoumaric acids; 3,5-diprenyl-4-hydroxycinnamic acid, 3prenyl-4-dihydro-cinamoyloxycinnamic acid, 2,2, -dimethyl6-carboxyethenyl-2H-1-benzopyran, lignanes; 3-acetoxymethyl5 - [(E) -2-formylethen-1-yl] -2- (4-hydroxy-3-methoxyphenyl) 7-methoxy-2,3-dihydrobenzofuran, Sesamine, Ascantin, Sesartenin and diterpenic acids; 15-oxo-3,13-Zcolavadiene-17-oic acid and its E-isomer, kommuric acid, imbrikatoloic acid, isocupressic acid (Bankova et al., 2000).

It has been found that compounds may exhibit cytotoxic activity; some of these compounds Flavonoids such as aromadendrine-4'methyl ether, 3,5,7-trihydroxy-6,4'dimethoxiflavone, Prenylated p-coumaric acids such as 3,5diprenyl-4-hydroxycinnamic acid (artepillin C) and 9-E-2dimethyl -6-carboxyethylene -8-prenyl-2H-1-benzopyran 
and lignanes such as 1- (4-hydroxy-3-methoxyphenyl)-1,2bis- [4 - [(E) -3-acetoxypropen-1-yl]-2-methoxyphenoxy $\}$ propan-3-ol acetate] and Yangambin and Ent-17-hydroxy3,13-Z-klerodadiene-15-oic acid, a diterpeneic acid (Bankova et al., 2000).

Propolis components that stimulate the immune system are 3-caffeoylquinic (chlorogenic) acid, 4-caffeoylquinic acid, 5-caffeoylquinic acid, 3,5-dicafeoylquinic acid and 4,5-dicafeoylquinic acid methyl ester from the caffeulquinic acids (Bankova et al., 2000).

Propolis extract, which may act in role against various DNA and RNA viruses (Burdock, 1998), might also be curative against viruses-induced infections on plants, animals and humans (Silici and Kutluca 2005; Wieckiewicz et al., 2013).

\section{What is the Importance of Propolis in Cancer Studies?}

There are many studies on the use of propolis or its active components in the treatment of cancer and demonstrating the potential of these biological components in the development of new anti-cancer agents. Several studies conducted in vivo and in vitro, propolis showed antitumor properties and was used during treatment; It has been concluded that by increasing the effect of chemotherapy, it enables the elimination of side effects of chemotherapy and allows high dose application (Bogdanov, 2016; Lee et al., 2005; Sforcin, 2007). Propolis has been used in many studies in cancer research. As a result of these studies, the most studied two propolis species have been identified several compounds that can show anticancer activity.

Active compounds of poplar propolis; CAPE (caffeic acid phenethyl ester), caffeic acid, apigenin, quercetin, genistein, routine, p-coumaric acid, ferulic acid, campferol, naringenin (Table 1) (Abubakar et al., 2014; Bogdanov, 2016).

Active compounds of Baccharis (Brazil) propolis; Artepillin C, baccharin, drupanin, cinnamic acid derivatives, prenylated p-coumaric acids, klerodone terpenes, benzofurans (Table 1) (Abubakar et al., 2014; Bogdanov, 2016).

Although studies in humans and mice have shown that the use of propolis does not cause side effects, its use for cancer treatment may also be relatively inexpensive. Ethanolic extract of propolis (EEP) and its phenolic compounds have shown biological activities such as immunomodulator, chemopreventive and antitumor (Sforcin, 2007). However, due to the possible negative effects of ethylalcohol, research on natural solvents and their effects on cancer has been concentrated. In fact, the anticarcinogenic effect of CAPE obtained by oil extractions is known (Artajo, 2006). The dissolution of propolis in vegetable oils by suitable methods is very important for health because of its usefulness in different industries and the additional benefits of the solvent used. Biological activities of propolis extracted in different vegetable oils, such as antimicrobial, antitumoral, anxiolytic and antidepressant, have been scientifically proven. For example, Ramanauskiene and Inkeniene (2011) showed that ferulic acid, coumaric acid and vanillin compounds were dominant in the propolis olive oil extract of Lithuania, and that the extract had antimicrobial effect, especially against $C$. albicans and B. cereus. The efficacy of the Brazilian propolis oil extract against $C$. albicans has also been demonstrated (Finger et al., 2013). In a study showing that Brazilian propolis fat extract has antitumoral properties in vitro and in vivo, it has been proved that fat extract is as effective as alcohol extract in preventing tumor growth. In the study where 4 phenolic acids and 3 flavonoids were identified in the oil extract of propolis, it was stated that the extract provided the inhibition of tumor cells in the best way (Carvalho et al., 2011). In a similar study, the antiproliferative effect of fat and ethanolic extracts against HL-60, MDA / MB-435 and SF-295 cells was demonstrated (Buriol et al., 2009). In another research; Propolis oil extract (OEP) has a stimulatory, anxiolytic and antidepressant effect on the central nervous system and therefore OEP can be used as a therapeutic agent for the treatment of anxiety and depression (Reis et al., 2014). In a clinical study of olive oil extract of propolis, it was shown that topical application of honey-propolis olive oil extract and beeswax was effective on oral mucositis (Abdulrhman et al., 2012). In a study conducted in Iran, it has been proved that propolis accelerates wound healing in STX-induced diabetic rats by adding olive oil extract, honey and royal jelly (Rashidi et al., 2016).

Cytotoxic effects of propolis extracts in many cell lines have been studied since 1979 with different in vitro methods (Ghisalberti, 1979). Hladon et al. (1980) studied the cytotoxic activities of propolis extracts on human $\mathrm{KB}$ (nasopharynx carcinoma) and HeLa (human cervical carcinoma) cell lines. The etheric propolis fraction (DEEP) exhibited strong cytotoxicity. Ethyl acetate and butanol fractions of DEEP showed good activity, while $\mathrm{CHCl} 3$ /DEEP showed moderate activity.

The killing activity of propolis on HeLa cells was tested by Ban et al. (1983). A concentration of $10 \mu \mathrm{g} / \mathrm{mL}$ of propolis inhibited $50 \%$ of the colony's ability to form. In addition to the lethal effect of propolis, flavonoids have also been tested. HeLa cells are more susceptible to quercetin and ramnetine, but less sensitive to galangine. Grunberger et al. (1988) described caffeic acid phenethyl ester as the compound which is partly responsible for the cytotoxic properties of propolis. The effect of CAPE on human cancer cell lines was determined in cultured breast carcinoma (MCF-7) and melanoma (SK-MEL-28 and SKMEL-170) cell lines.

Table 1 Biologically active ingredients in poplar and Baccharis propolis (Abubakar et al., 2014).

\begin{tabular}{|c|c|}
\hline \multicolumn{2}{|c|}{ Active ingredients Anticancer and antitumor } \\
\hline $\begin{array}{l}\text { Baccharis propolis } \\
\text { artepillin C, baccharin, drupanin, cinnamic acid } \\
\text { derivatives, prenylated p-coumaric acids, clerodane } \\
\text { diterpenes, benzofuranes, and caffeoylquinic acid } \\
\text { derivatives. }\end{array}$ & $\begin{array}{l}\text { Poplar propolis } \\
\text { caffeic acid, caffeic acid phenylethyl ester, apigenin, } \\
\text { quercetin, genistein, galangin, luteolin, fisetin, ferulic acid, } \\
\text { chrysin, acacetin, p-hydroxy-benzoic acid, p-methoxy- } \\
\text { benzoic acid, gallic acid, and vanillic acid. }\end{array}$ \\
\hline
\end{tabular}


A dose of $10 \mu \mathrm{g} / \mathrm{ml}$ of CAPE inhibited the addition of $\left[{ }^{3} \mathrm{H}\right]$ thymidine to DNA in breast cancer. More dramatic effects have been observed in melanoma, colon (HT 29) and renal carcinoma cell lines, but the effect of CAPE on normal melanocytes and fibroblasts was significantly lower. As the cytotoxic effect of CAPE is more effective in transformed cells, we can say that propolis is responsible for the carcinostatic properties. Antitumor activity of caffeic acid derivatives such as methyl ferulate, methyl acetyl ferulate, methyl acetyl isoferulate and methyl diacetyl caffeate has been reported (Inayama et al., 1984). The cytotoxic effect of propolis in vitro against ovarian cancer cell lines created in Chinese hamster experimental animals was stated to be due to the naphthalene residues contained in propolis (Ross, 1990). Brazilian propolis extracts obtained from an Apis mellifera species on human hepatocellular carcinoma, KB and HeLa cell lines have been reported to show cytotoxic effects caused by propolis quercetin, caffeic acid and phenyl ester components by in vitro tests (Matsuno, 1992).

Matsuno (1995) isolated klerodone diterpenoid from propolis and showed that the inhibition of human hepatocellular carcinoma cells $(\mathrm{HuH} \mathrm{13)}$ at a dose of 10 $\mu \mathrm{g} / \mathrm{mL}$ and lethality at a dose of $20 \mu \mathrm{g} / \mathrm{mL}$, resulting in a lethal effect on human lung carcinoma (HLC-2). It has also been showed that primary rabbit kidney cells had a survival rate of $75 \%$ at a dose of $100 \mu \mathrm{g} / \mathrm{mL}$. The susceptibility of cells to CAPE-related cell death can be determined by reduced regulation of normal redox status in transformed cells (Chiao et al., 1995).

The aqueous extract of Japanese propolis (AEP) inhibited the growth of S-180 mouse sarcoma in vitro. In addition, administration of AEP to the mouse significantly inhibited the growth of transplanted tumor cells (Inoue et al., 2008).

Orsolic (2010) states that the chemopreventive activity of propolis in animal models and cell cultures is due to its ability to inhibit DNA synthesis in tumor cells, to induce tumor cells to apoptosis, and to activate macrophages that produce factors that regulate the functions of B-, T-and NK-cells.

Propolis and some isolated polyphenolic substances (caffeic acid, caffeic acid phenyl ester and quercetin) reduced the number of tumor nodules in the lung (Ozkul et al., 2005). Although most polyphenols have anti-metastatic effect, caffeic acid phenyl ester from poplar propolis and Artepilin C compound from Baccharis propolis have been identified as the most potent antitumor agents. Regular use of propolis as a food supplement provides a protective effect against cancer-causing mutations in humans (Bogdanov, 2016).

Turkish propolis has also been reported to exhibit anticarcinogenic properties (Piredda et al., 2015; Catchpole et al., 2015) and explained the inhibition of leucine, uridine and thymidine addition in carcinoma cells and thus inhibition of DNA synthesis by the antitumor activity of flavonoids.

Numerous studies have been demonstrated the effect of propolis on cell culture and animal testing (Awale et al., 2008; Orsolic, 2010; Catchpole et al., 2015). In other words, several studies indicating that propolis can be consumed with regular anticancer effect. Regular consumption of propolis as a food supplement can be protective against cancer caused by mutations in humans (Riberio and Salvadori, 2003). Human papilloma virus (HPV), which is the most common cause of cervical cancer in women especially in developed countries, is a great threat for women. There is a study showing that HPV infections can be eliminated as a result of local treatment with propolis for six months (Iljazovic et al., 2006). In a similar study, 76\% PAP smear development was prevented by using propolis (Imhof et al., 2005).

The water-miscible extract of CAPE-rich propolis has nearly been completely suppressed the growth of human NF1 cancer and human NF2 Schwannoma tumor, called MPNST (malignant peripheral nerve sheath tumor) (Demestre et al., 2009).

Controlled clinical studies have shown that propolis inhibits oral mucositis in breast cancer patients (Piredda et al., 2015).

The antitumor effects of phenolic components of propolis include pinosembrine, pinobanksin-3-O-acetate, tectocrizine, dimethylallyl caffeate, 3-methyl-3-butenyl caffeate, benzyl ferulate and benzyl isoferulate were investigated onto the gastro-intestinal cell lines; HCT-116 showed good activity in anti-proliferative analyzes against colon carcinoma, KYSE30 esophageal squamous carcinoma and NCI-N87 gastric carcinoma (Catchpole et al., 2015). Chinese and Brazilian EEP showed anticancer activity in 4 human colon carcinoma cell lines (CaCo, HCT116, HT-29 and SW480) and increased dose-dependent inhibition in both extracts. Chinese propolis induces apoptosis and caused a dose-dependent increase in cellular mRNA levels of proteins associated with tumor suppression (p21CIP1 and p53) in HCT116 cell lines (Ishiara et al., 2009). The active compounds of the Netherlands propolis, benzyl, phenethyl and cinnamyl caffeates, have been determined to show antiproliferative activities on the colon 26-L5 carcinoma (Banskota et al., 2002). Chrysin has acting the TNFa signaling pathway and in this way markedly sensitizes human cancer cells to TNFa-induced apoptosis ( $\mathrm{Li}$ et al., 2010). Galangin, another component of propolis, has been shown to induce apoptosis and suppress proliferation in vitro tests against the gastric cancer cell line SNU-484 (Kim et al., 2012). Pinosembrine has shown activity against human adenocarcinoma HCT 116 cell line. The mechanism of action is triggered by Bax-dependent mitochondrial apoptosis but non-Bax-expressing HCT 116 cells have been shown to be immune to pinosembrine (Kumar et al., 2007).

Ethanolic extract of Brazilian red propolis has been reported to exhibit $100 \%$ cytotoxic activity against the human pancreatic cancer PANC-1 cell line (Awale et al., 2008). In this study, 43 compounds (3 of which were new) were isolated. All isolated compounds were tested against PANC-1 cells under nutrient-free conditions. A component of propolis [(6aR, 11aR) -3,8-dihydroxy-9methoxypterocarpan] showed cytotoxicity (100\%) over time in a non-apoptotic manner that did not lead to DNA fragmentation, but accompanied by necrotic type morphological changes (Awale et al., 2008).

In studies on the anticancer and anti-inflammatory activity of propolis, it is thought that polyphenols found in poplar propolis are responsible especially for the crysin and caffeic acid phenethyl ester (CAPE) (Araújo et al., 2011; Chan et al., 2013; Jaganathan and Mandal, 2009; Sawicka et al., 2012). 
The search for new drugs that can function as chemotherapeutic agents and have low side effects, especially derived from natural products, have been increased in recent years (Watanabe et al., 2011; Franchi et al., 2012). Propolis also induced the apoptosis in a Blymphoma cancer cell line. This apoptotic effect of propolis leads to loss of mitochondrial membrane potential and this pathway is activated by caspase signaling (Figure 1) (Alday-Provencio et al., 2015; Sawicka et al., 2012). Campos et al. (2014) reported that the ethanolic extract of propolis from M. orbignyi (EEP) showed the cytotoxic activity against the human K562 erythro leukemia cell line and that despite the fact that the resistance to certain chemotherapeutic agents, the number of these cells decreased with the application of EEP.

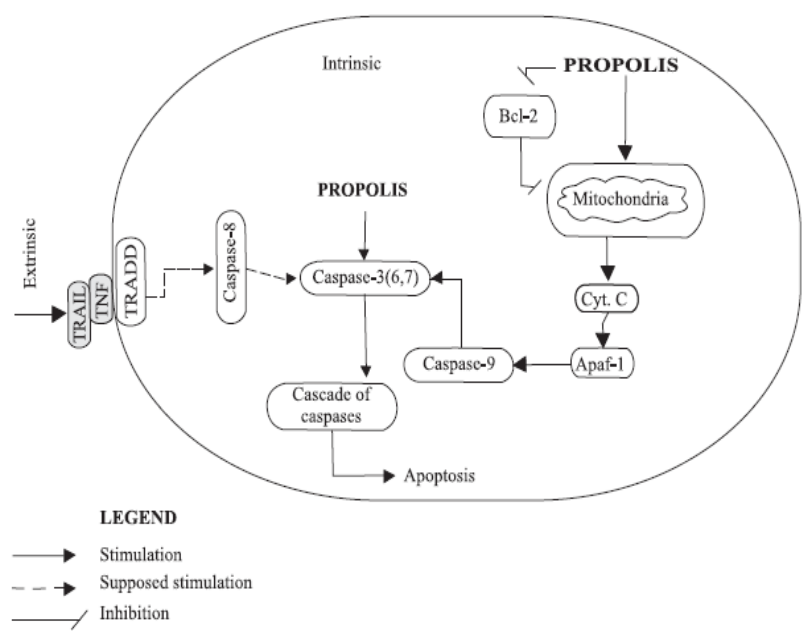

Figure 1. Effect of propolis on apoptosis pathways in cancer cells (Sawicka et al., 2012)

The antitumor effect of propolis is due to the inclusion of flavonoids such as terpenes and caffeic acid phenethyl ester, which is thought to be responsible for the synergy between these substances (Watanabe et al., 2011; Valente et al., 2011). The synergy between propolis and anticancer agents is quite interesting. Therefore, propolis flavonoids act a protective role against the toxicity of radiation and chemotherapeutic agents especially on mice. It would also suggest that it might have similar activity in humans. Combination with antioxidant therapy might be improve the side effects of chemotherapy on leukocytes, liver and kidney, and thereby increase the effect of chemotherapy on dose dependent.

According to the studies, the use of propolis as a preventive and supportive will shed light on the future synergistic effects of pharmaceutical drugs.

\section{References}

Abdulrhman M, Elbarbary NSD, Amin DA, Ebrahim RS. 2012. Honey and a Mixture of Honey, Beeswax, and Olive OilPropolis Extract in Treatment of Chemotherapy-Induced Oral Mucositis: A Randomized Controlled Pilot Study. Pediatr Hematol Oncol. 29: 285-292. DOI: 10.3109/08880018 .2012 .669026 .

Abubakar MB, Abdullah WZ, Sulaiman SA, Ang BS. 2014. Polyphenols as Key Players for the Antileukaemic Effects of Propolis. Evidence-Based Complementary and Alternative Medicine Volume 2014, Article ID 371730, 11 pages. DOI:10.1155/2014/371730.
Alday-Provencio S, Diaz G, Rascon L, Quintero J, Alday E, Robles-Zepeda R, Garibayescobar A, Astiazaran H, Hernandez J, Velazquez C. 2015. Sonoran Propolis and Some of its Chemical Constituents Inhibit in vitro Growth of Giardia lamblia Trophozoites. Planta Med. 81(9): 742-7. DOI: $10.1055 / \mathrm{s}-0035-1545982$.

Araújo JR, Gonçalves P, Martel F. 2011. Chemopreventative effect of dietary polyphenols in colorectal cancer cell lines, Nutr. Res. 31: 77-87. DOİ: 10.1016/j.nutres. 2011.01.006.

Artajo LS. 2006. Phenolic Compounds: Their Role during Olive Oil Extraction and in Flaxseed-Transfer and Antioxidant Function". A thesis submitted to the Faculty of Agronomical Engineer of the University of Lleida in partial fulfillment of the requirements of the degree of Doctorate of Philosophy. Lleida Spain.

Awale S, Li F, Onozuka H, Esumi H, Tezuka Y, Kadota S. 2008. Constituents of Brazilian red propolis and their preferential cytotoxic activity against human pancreatic PANC-1 cancer cell line in nutrient-deprived condition. Bioorg Med Chem. 16: 181-189. DOI: 10.1016/j.bmc.2007.10.004

Ban J, Popovic S, Maysinger D. 1983. Cytostatic effects of propolis in vitro. Acta Pharm Jugosl. 33: 245-255.

Bankova V, Marcucci M, Castro S. 2000. Propolis recent advances in chemistry and plant origin, Apidologie. 31: 3-15. DOI: 10.1051/apido:2000102.

Banskota AH, Nagaoka T, Sumioka LY, Tezuka Y, Awale S, Midorikawa K, Matsushige K, Kadota S. 2002. Antiproliferative activity of the Netherlands propolis and its active principles in cancer cell lines. J Ethnopharmacol. 80(1): 67-73.

Bogdanov S. 2016. Propolis: Composition, Health, Medicine: A Review. Bee Product Science. www.bee-hexagon.net.

Burdock G. 1998. A review of the biological properties and toxicity of bee propolis (propolis). Food Chem Toxicol. 36: 347-63.

Buriol L, Finger D, Schmidt EM, Dos Santos JMT, Da Rosa MR, Quináia SP, E Torres YR. 2009. Chemical Composition and Biological Activity of Oil Propolis Extract: An Alternative To Ethanolic Extract. Quim Nova. 32(2): 296-302.

Campos JF, Santos UP, Macorini LFB, Melo AMMF, Balestieri JBP, Paredes-Gamero EJ, Cardoso CAL, Souza KP, Santos EL. 2014. Antimicrobial, antioxidant and cytotoxic activities of propolis from Melipona orbignyi (Hymenoptera, Apidae). Food Chem Toxicol. 65: 374-380. DOI: 10.1016/j.fct.2014.01.008.

Cantarelli MA, Camina JM, Pettenati EM, Marchevsky EJ, Pellerano RG. 2011. Trace mineral content of Argentinean raw propolis by neutron activation analysis (NAA): Assessment of geographical provenance by chemometrics. LWT - Food Science and Technology. 44: 256-260. DOI: $10.1016 /$ j.lwt.2010.06.031.

Carvalho AA, vd. 2011. In vivo antitumoural activity and composition of an oil extract of Brazilian propolis. Food Chem. 126: 1239-1245. DOI:10.1016/j.foodchem. 2010.12.035

Castaldo S, Capasso F. 2002. Propolis, an old remedy used in modern medicine. Fitoterapia, 73 Suppl 1: 1-6. DOI: 10.1016/S0367-326X (02)00185-5.

Catchpole O, Mitchell K, Bloor S, Davis P, Suddes A. 2015. Antiproliferative activity of New Zealand propolis and phenolic compounds vs human colorectal adenocarcinoma cells. Fitoterapia, 106: 167-174. DOI: 10.1016/j.fitote. 2015.09.004.

Chan GC, Cheung KW, Sze DM. 2013. The immunomodulatory and anticancer properties of propolis. Clin. Rev. Allergy Immunol. 44 (3): 262-273. DOI: 10.1007/s12016-012-8322-2.

Chiao C, Carothers AM, Grunberger D, Solomon G, Presto GA, Barrett JCD. 1995. Apoptosis and altered redox state induced by cafeic acid phenethyl ester (CAPE) in transformed rat (Bbroblast cells. Cancer Research. 55: 3576 \pm 3583 . 
Demestre M, Messerli S, Celli N, Shahhossini MKL, Mautner V, Maruta H. 2009. CAPE (caffeic acid phenethyl ester)-based propolis extract (Bio 30) suppresses the growth of human neurofibromatosis (NF) tumor xenografts in mice. Phytotherapy Res. 23: 226-230. DOI: 10.1002/ptr.2594.

Doğan H, Akyol E, Akgül H, Selamoğlu TZ. 2014. Biologic Activity of Honeybee Products Obtained From Different Phytogeographical Regions of Turkey. Turkish Journal of Agriculture - Food science and Technology 2(6): 273-276.

Finger D, Machado CS, Torres YR, Quınáia SP, Thomaz ACG, Gobbo AR, Monteiro MC, Ferreira AG, Sawaya A, Frankland $\mathrm{CH}$, Eberlin MN. 2013. Antifungal Bioassay-Guided Fractionation of an Oil Extract Of Propolis. Journal Of Food Quality. 36: 291-301. DOI: 10.1111/jfq.12039.

Franchi GC Jr, Moraes CS, Toreti VC, Daugsch A, Nowill AE, Park YK. 2012. Comparison of effects of the ethanolic extracts of Brazilian propolis on human leukemic cells as assessed with the MTT assay. Evid. Based Complement. Alternat Med. 2012: 1-6. DOI: 10.1155/2012/918956.

Ghisalberti, E.L. 1979. Propolis: A review. Bee World. 60: 5984. DOI: 10.1080/0005772X.1979.11097738.

Grunberger D, Banerjee R, Eisinger K, Oltz EM, Efros L, Caldwell M, Estevez V, Nakanishi K. 1988. Preferential cytotoxicity on tumor cells by caffeic acid phenethyl ester isolated from propolis. Experientia. 44: 230-232. DOI: 10.1007/bf01941717.

Güney F, Y1lmaz M. 2013. Propolisin Kimyasal İçeriği ile Antibakteriyel, Antiviral, Antitümör, Antifungal ve Antioksidan Aktivitesi, Arıcılık Araştırma Dergisi /Aralık.

Hladón B, Bylka W, Ellnaim-Wojtaszek M, Skrzypczak L, Szafarek P, Chodera A, Kowalewski Z. 1980. In vitro studies on the cytostatic activity of propolis extracts. Arzneim-Forsch Drug Res. 30: 1847-1848.

Iljazovic E, Ljuca D, Sahimpasic A, Avdic S. 2006. Efficacy in treatment of cervical HRHPV infection by combination of beta interferon, and herbal therapy in woman with different cervical lesions. Bosn J Basic Med Sci. 6: 79-84. DOI: 10.17305/bjbms.2006.3128.

Imhof M, Lipovac M, Kurz C, Barta J, Verhoeven HC, Huber JC. 2005. Propolis solution for the treatment of chronic vaginitis. International Journal of Gynaecology and Obstetrics, 89(2): 127-132. DOI: 10.1016/j.ijgo.2005.01.033.

Inayama S, Harimaya K, Hori H, Okhura T, Kawamata T, Hıkıchı M, Yokokura T. 1984. Studies on Non-sesquiterpenoid Constituents of Gaillardia pulchella. II. Less Lipophilic Substances, Methyl Caffeate as an Antitumor Catecholic. Chem Pharm Bull. 32: 1135-1141. DOI: https://doi.org /10.1248/cpb.32.1135.

Inoue K, Saito M, Kanai T, Kawata T, Shigematsu N, Uno T, Isobe K, Liu CH, Ito H. 2008. Anti-tumor effects of watersoluble propolis on a mouse sarcoma cell line in vivo and in vitro. Am J Chin Med. 36: 625-634. DOI: 10.1142/S0192415X0800603X.

Ishihara M, Naoi K, Hashita M, Itoh Y, Suzui M. 2009. Growth inhibitory activity of ethanol extracts of Chinese and Brazilian propolis in four human colon carcinoma cell lines. Oncol Rep. 22: 349-354. DOI: 10.3892/or_00000444.

Reis JSS, Oliveira GB, Monteiro MC, Machado CS, Torres YR, Prediger RD, Maia CSF. 2014. Antidepressant- and anxiolytic-like activities of an oil extract ofpropolis in rats Phytomedicine 21:1466-1472.

Kim AD, Jeon YK, Nam MJ. 2012. Galangin induces apoptosis in gastric cancer cell lines via regulation of ubiquitin carboxyterminal hydrolase isozyme L1 and glutathione S-transferase P, Food Chem Toxicol. 50: 684-688. DOI: 10.1016/j.fct.2011.11.039.

Konishi S, Sawaya A, Custódio AR, Cunha I, Shimizu M. 2004. Influence of solubilising agents on antimicrobial activity of propolis extracts and hydro alcoholic spray formula. Mensagem Doce. 75: 22-25.
Kumar MAS, Nair M, Hema PS, Santhoshkumar TR. 2007. Pinocembrin triggers Bax dependent mitochondrial apoptosis in colon cancer cells. Mol Carcinog. 46: 231-241. DOI: $10.1002 / \mathrm{mc} .20272$.

Kumazawa S, Hamasaka T, Nakayama T. 2004. Antioxidant activity of propolis of various geographic origins. Food Chem. 84: 329-339. DOI: https://doi.org/10.1016/S03088146(03)00216-4.

Kutluca S, Genç F, Korkmaz A. 2006. Propolis. T.C. SAMSUN VALİLIĞİ İl Tarım Müdürlüğü, Samsun.

Lee YT, Don MJ, Hung PS, Shen YC, Lo YS, Chang KW, Chen CF, Ho LK. 2005. Cytotoxic of phenolic acid phenethyl esters on oral cancer cells. Cancer Letters. 223: 19-25. DOI: 10.1016/j.canlet.2004.09.048.

Li X, Huang Q, Ong CN, Yang XF, Shen HM. 2010. Chrysin sensitizes tumor necrosis factor- $\alpha$-induced apoptosis in human tumor cells via suppression of nuclear factor-kappaB. Cancer Lett. 293: 109-116. DOI: 10.1016/j.canlet. 2010.01.002

Jaganathan SK, Mandal M. 2009. Antiproliferative effects of honey and of its polyphenols: a review. J. Biomed Biotechnol. 2009: 830616. DOI: 10.1155/2009/830616.

Marcucci MC, Ferreres F, Bankova VS, De Castro SL, Dantas AP, Valente PH, Paulino N. 2001. Phenolic compounds from Brazilian popolis with pharmacological activities. J Ethnopharmacol. 74: 105-112. DOI: $10.1016 /$ S03788741(00)00326-3.

Marcucci MC. 1995. Propolis: Chemical Composition, Biological Properties And Therapeutic Activity. Apidologie. 26: 83-99. DOI: 10.1051/apido: 19950202.

Matsuno T. 1992. Isolation and characterization of the tumoricidal substances from Brazilian propolis. Honeybee Sci. 13: 49-54.

Matsuno T. 1995. A new clerodane diterpenoid isolated from propolis. Zeitschrift fuÈr Naturforschung Section C (A Journal of Biosciences). 50: 93-97. DOI: https://doi.org /10.1515/znc-1995-1-214.

Mello BCBS, Petrus JCC, Hubinger MD. 2010. Concentration of flavonoids and phenolic compounds in aqueous and ethanolicpropolis extracts through nanofiltration. Journal of Food Engineering. 96: 533-539. DOI: 10.1016 /j.jfoodeng.2009.08.040.

Moreno MIN, Isla MI, Sampietro AR, Vattuone MA. 2000. Comparison of The Free Radical-Scavenging Activity of Propolis from Several Regions of Argentina. J Ethnopharmacol. 71: 109-114. DOI: 10.1016/S0378-8741 (99)00189-0.

Moura SAL, Negri G, Salatıno A, Da Cunha Lima LD, Dourado LPA, Mendes JB, Andrade SP, Ferreira MAND, Cara DC. 2009. Aqueous Extract Of Green Propolis: Primary Components, Evaluation Of İnflammation And WoundHealing By Using Subcutaneous İmplanted Sponges. Evid Based Complement Alternat Med. 2011: 1-9. DOI: 10.1093/ecam/nep112.

Orsolic N. 2010. A review of propolis antitumour action in vivo and in vitro. JAAS 2 (1). 1-20. DOI: 10.3896/IBRA.4.02.1.01.

Ozkul Y, Silici S, Eroğlu E. 2005. The anticarcinogenic effect of propolis in human lymphocytes culture. Phytomedicine, 12(10): 742-747. DOI: 10.1016/j.phymed.2004.06.015.

Özan F. 2006. Propolis'in Kırık İyileşmesi Üzerine Etkilerinin Deneysel Olarak İncelenmesi. Doktora Tezi. Cumhuriyet Üniversitesi, Sağlık Bilimleri Enstitüsü, Sivas.

Piredda M, Facchinetti G, Stan I, Durante G, Vincenzi B, Armento G, D'onofrio L, Tonini G, De Marinis M. 2015. Propolis for prevention of chemo-induced oral mucositis in breast cancer patients: A randomized controlled trial. Annals of Oncology. DOI: 10.1093/annonc/mdv345.01.

Ramanauskiene K, Inkeniene AM. 2011. Propolis oil extract: quality analysis and evaluation of its antimicrobial activity. Nat Prod Res. 25(15): 1463-1468. DOI: 10.1080/14786419. 2010.529440 . 
Rashidi MK, Mirazi N, Hosseini A. 2016. Effect of topical mixture of honey, royal jelly and olive oil-propolis extract on skin wound healing in diabetic rats. Wound Med. 12: 6-9. DOI: $10.1016 /$ j.wndm.2015.12.001.

Ribeiro LR, Salvadori DMF. 2003. Dietary components may prevent mutation-related diseases in humans. Mutation Research-Reviews in Mutation Research. 544(2-3): 195-201. DOI: 10.1016/j.mrrev.2003.06.019.

Ross PB. 1990. The effects of propolis fractions on cells in tissue culture. MPhil thesis, University of Wales College of Cardiff, UK, $193 \mathrm{p}$.

Sawicka D, Car H, Borawska MH, Nikliński J. 2012. The anticancer activity of propolis, Folia Histochem Cytobiol. 50: 25-37. DOI: 10.5603/18693.

Schmidt JO. 1997. Bee Product Chemical Composition and Application. International Coference on: Bee Product: Properties, Applications and Apitherapy, Israel, P:15.

Sforcin JM. 2007. Propolis and the immune system: a review. J Ethnopharmacol. 113: 1- 14. DOI: 10.1016/j.jep. 2007.05.012.

Silici S, Güçlü BK. 2010. Yumurtacı damızlık japon bıldırcın (Coturnix japonica) rasyonlarına propolis ve kafeik asit katılmasının verim ve kuluçka performansı ile yumurta kalitesi ve bazı serum parametrelerine etkisi. Sağlık Bilimleri Dergisi (Journal of Health Sciences) 19 (2): 140-150.
Silici S, Kutluca S. 2005. Chemical composition and antibacterial activity of propolis collected by three different races of honeybees in the same region. J Ethnopharmacol. 99 (1): 69 73. DOI: $10.1016 /$ j.jep.2005.01.046

Silici S. 2003. Propolisin bazı antimikrobiyal ve farmakolojik aktiviteleri üzerine bir araştırma. Çukurova Üniversitesi, Fen Bilimleri Enstitüsü, Zootekni Anabilim Dalı, Adana.

Şahinler N. 2000. Arı Ürünleri ve İnsan Sağlığı Açısından Önemi. MKÜ Ziraat Fakültesi Dergisi. 5 (1-2): 139-148.

Valente MJ, Baltazar AF, Henrique R, Estevinho L, Carvalho M. 2011. Biological activities of Portuguese propolis: Protection against free radical-induced erythrocyte damage and inhibition of human renal cancer cell growth in vitro. Food Chem Toxicol. 49: 86-92. DOI: 10.1016/j.fct.2010.10.001.

Watanabe MAE, Amarante MK, Conti BJ, Sforcin JM. 2011. Cytotoxic constituents of propolis inducing anticancer effects: a review. J Pharm Pharmacol. 63: 1378-1386. DOI: 10.1111/j.2042-7158.2011.01331.x.

Wieckiewicz W, Miernik M, Wieckiewicz M, Morawiec T. 2013. Does Propolis Help to Maintain Oral Health? Evidence-based complementary and alternative medicine. 2013(1): 351062. DOI: $10.1155 / 2013 / 351062$. 